\title{
ДОСЛІДЖЕННЯ ВПЛИВУ ЕКСТРАКТІВ 3 ЛИСТЯ СТЕВІЇ ТА ЧОРНИЦІ НА ПОКАЗНИКИ РОЗВИТКУ ЕКСПЕРИМЕНТАЛЬНОГО ЦУКРОВОГО ДІАБЕТУ, ІНДУКОВАНОГО ВИСОКОФРУКТОЗНОЮ ДІЄТОЮ 3 ДОДАВАННЯМ ІН'ЄКЦІЙ ДЕКСАМЕТАЗОНУ
}

Вступ. Цукровий діабет 2 типу - метаболічне захворювання, що характеризується хронічною гіперглікемією, яка розвивається в результаті порушення секреції інсуліну або механізмів його взаємодії з клітинами тканин. Відомо, що головною причиною розвитку серцево-судинних ускладнень є гіперглікемія.

Мета дослідження - вивчити вплив сухих екстрактів з листя стевії та чорниці на розвиток метаболічних порушень у щурів при експериментальному цукровому діабеті, спричиненому дексаметазоном на фоні високофруктозної дієти.

Методи дослідження. У сироватці крові визначали концентрацію глікозильованого гемоглобіну, рівень фрруктозаміну, площу під глікемічними кривими, рівень імунореактивного інсуліну. Показники ліпопероксидації визначали за вмістом дієнових кон'югатів та ТБК-реактивних продуктів, стан антиоксидантної системи оцінювали шляхом визначення концентрації відновленого глутатіону. Значимість міжгрупових відмінностей оцінювали за t-критерієм Стьюдента.

Результати й обговорення. Введення лабораторним тваринам низьких доз дексаметазону викликало комплекс порушень, характерних для метаболічного синдрому та діабету 2 типу. Так, за вказаних умов у сироватці крові щурів спостерігали підвищення рівня глікозильованого гемоглобіну, концентрації фрруктозаміну, вмісту глюкози, рівня базальної глікемії, збільшення площі під глікемічними кривими. При введенні сухих екстрактів з листя стевії та чорниці на фоні їх сумісного введення з дексаметазоном відзначали нормалізуючий вплив цих речовин на показники, які досліджували.

Висновки. Використання сухих екстрактів з листя стевії та чорниці проявляє нормалізуючу дію на показники глікозилювання, рівень глюкози, показники ліпідного обміну в сироватці крові щурів при цукровому діабеті 2 типу. Показано більш виражену антиоксидантну дію екстракту з листя чорниці та гіпоглікемічну дію екстракту з листя стевії. Це свідчить про доцільність сумісного застосування екстрактів з листя стевії та чорниці з метою створення на їх основі лікарських засобів для корекції метаболічних порушень.

КЛЮЧОВІ СЛОВА: екстракт з листя стевії (Stevia rebaudiana Bertoni); екстракт з листя чорниці (Vaccinum myrtillus); цукровий діабет 2 типу; інсулінорезистентність; дексаметазон.

ВСТУП. Цукровий діабет 2 типу (ЦД 2) - метаболічне захворювання, що характеризується хронічною гіперглікемією, яка розвивається в результаті порушення секреції інсуліну або механізмів його взаємодії з клітинами тканин. Відомо, що головною причиною розвитку серцево-судинних ускладнень є гіперглікемія. Остання призводить до інтенсивного утворення вільних радикалів, які є тригерами процесів ліпопероксидації, що, у свою чергу, сприяє розвитку атеросклерозу.

На фрармацевтичному ринку України зареєстровано ряд синтетичних лікарських препаратів, які використовують для корекції стану та лікування хворих на ЦД 2. Проте з'ясовано, що син(с А. Л. Загайко, О. І. Чумак, 2017. тетичні препарати мають ряд побічних есректів, серед яких - активація вільнорадикальних процесів окиснення. На сьогодні фрітотерапія стає важливою складовою частиною лікування та профрілактики метаболічних порушень. ІІї можна використовувати за певних стадій ЦД 2 як монотерапію в комбінації з дієтотерапією, а також при сумісному застосуванні із цукрознижувальними засобами та/або інсуліном. Досліджено, що рослинні глікозиди та фрлавоноїди можуть проявляти гіпоглікемічну та антиоксидантну дію.

Стевія (Stevia rebaudiana Bertoni) € багаторічною рослиною родини айстрові (Asteraceae). Відомо, що листя даної рослини містить дитерпенові глікозиди, які майже в 40 разів солодші 
за сахарозу. Стевіол є основним структурним компонентом глікозиду стевії [1]. У ряді країн рослину використовують як цукрозамінник [2]. Стевіозид, компонент листя стевії, має гіпоглікемічну, протизапальну та гіпертензивну дію, що проявляється зниженням рівня глюкози, глікозильованого гемоглобіну в крові пацієнтів із цукровим діабетом [3, 4]. Стевія входить до складу типових зборів, збагачених мікроелементами, для хворих на ЦД 2 [5].

Чорниця звичайна (Vaccinium myrtillus L.) $€$ багаторічною рослиною родини вересові (Ericaceae). В її листі переважають фрлавоноїди, протоантоціанідини, тритерпени, а також фенольні сполуки, зокрема полімірилін, який використовують у водних настоях для лікування початкових стадій ЦД 2 [6, 7]. Експериментально доведено, що препарати 3 листя чорниці звичайної також застосовують для зниження рівня цукру в крові при ЦД 2 у складі рослинних зборів [8].

Мета дослідження - вивчити вплив сухих екстрактів 3 листя стевії та чорниці на розвиток метаболічних порушень у щурів при експериментальному цукровому діабеті, спричиненому дексаметазоном на фроні високофрруктозної дієти.

МЕТОДИ ДОСЛІДЖЕННЯ. Експеримент виконували на щурах-самцях лінії Вістар масою 160-200 г, яких утримували в умовах природної зміни режиму освітлення, температури та вологості повітря за стандартами віварію НФаУ на висофруктозній дієті з введенням низьких доз дексаметазону, як описано в роботі [9]. Піддослідних тварин було поділено на групи: 1-ша інтактні тварини, яких утримували на стандартному раціоні віварію; 2-га - тварини, яким, поряд із високофрруктозною дієтою (2 г фрруктози на 100 г маси тіла на добу), підшкірно щодня протягом 6-ти тижнів вводили дексаметазон у дозі 2 мг/100 г маси тіла; 3-тя - тварини, яким протягом 2-х тижнів на фроні введення дексаметазону внутрішньошлунково вводили сухий екстракт 3 листя стевії у дозі 9 мг/100 г маси тіла; 4-та тварини, яким протягом 2-х тижнів на фроні введення дексаметазону внутрішньошлунково вводили сухий екстракт з листя чорниці у дозі 9 мг/100 г маси тіла.

Тварин декапітували під хлоразоло-уретановим наркозом. Об'єктом дослідження були сироватка крові та печінка щурів. При виконанні дослідження дотримувалися Загальних етичних принципів експериментів на тваринах (Україна, 2001), гармонізованих з Європейською конвенцією про захист хребетних тварин, що використовуються для дослідних та інших наукових цілей [10].
У сироватці крові визначали концентрацію глікозильованого гемоглобіну (HbA1C) імунотурбідиметричним методом, рівень фрруктозаміну - спектросротометричним методом 3 використанням тетразолію нітросинього, площу під глікемічними кривими (ПГК) при проведенні внутрішньочеревного тесту толерантності до глюкози (ВЧТТГ) розраховували за допомогою комп'ютерної програми Mathlab, вміст глюкози - із застосуванням стандартних наборів фрірми "Філісіт-Діагностика" (Україна), рівень імунореактивного інсуліну (IPI) - 3 використанням стандартних наборів фрірми "РИО-ИПС-ПГ". Показники ліпопероксидації визначали за вмістом дієнових кон'югатів (ДК) та ТБК-реактивних продуктів (ТБК-РАП) - за реакцією з тіобарбітуровою кислотою спектрофотометричним методом [11], стан антиоксидантної системи оцінювали шляхом визначення концентрації відновленого глутатіону (GSH) - спектрофотометрично за реакцією з алоксаном, а також глутатіонредуктази (ГР) [12]. Глюкозний гомеостаз у експериментальних і контрольних тварин оцінювали в різні терміни після відтворення моделі (7, 14 і 21 дні) за показниками базальної глікемії і ВчТТГ (3 г/кг маси тіла). Статистичну обробку отриманих даних проводили 3 використанням програми STATISTICA (StatSoft Inc., США, версія 6.0). Значимість міжгрупових відмінностей оцінювали за t-критерієм Стьюдента.

РЕЗУЛЬТАТИ Й ОБГОВОРЕННЯ. ВвеДеНнЯ лабораторним тваринам низьких доз дексаметазону викликало комплекс порушень, характерних для метаболічного синдрому та діабету 2-го типу. Так, за вказаних умов у сироватці крові щурів спостерігали підвищення рівня глікозильованого гемоглобіну, концентрації фрруктозаміну, вмісту глюкози, рівня базальної глікемії, збільшення площі під глікемічними кривими (табл. 1). Це можна пояснити зниженням утилізації глюкози периферичними тканинами внаслідок пригнічення дексаметазоном експресії транспортерів глюкози GLUT1 та GLUT4 [13].

Рівень НbA1C - інформативний показник есрективності контролю рівня глюкози у крові. Швидкість синтезу глікозильованого гемоглобіну залежить від величини гіперглікемії, а нормалізацію його рівня спостерігають через 1-1,5 міс. після досягнення еуглікемії [14], тому вміст НbA1C $€$ адекватним показником компенсації вуглеводного обміну у хворих на діабет протягом тривалого часу, а збільшення рівня даного показника може відображати розвиток ретинопатії, нефропатії та інших ускладнень ЦД 2 [15]. До того ж, крім гемоглобіну, неферментативному глікозилю- 
Таблиця 1 - Вміст глікозильованого гемоглобіну, фруктозаміну, рівень базальної глікемії, площа під глікемічними кривими, рівень імунореактивного інсуліну в сироватці крові

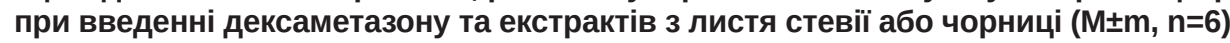

\begin{tabular}{|l|c|c|c|c|}
\hline \multicolumn{1}{|c|}{ Показник } & Інтакт & Дексаметазон & Декс+стевія & Декс+чорниця \\
\hline Глікозильований гемоглобін, \% & $7,5 \pm 0,5$ & $9,6 \pm 0,7^{*}$ & $8,6 \pm 0,7^{\star \#}$ & $8,4 \pm 0,6^{\star *}$ \\
\hline Фруктозамін, ммоль/л & $1,91 \pm 0,12$ & $3,6 \pm 0,29^{*}$ & $3,1 \pm 0,26^{*}$ & $2,45 \pm 0,24^{\star \#}$ \\
\hline Базальна глікемія, ммоль/л & $4,04 \pm 0,11$ & $13,42 \pm 0,38^{*}$ & $5,06 \pm 0,27^{\#}$ & $12,08 \pm 0,24^{*}$ \\
\hline ПГК, ммоль/л/хв & $625,44 \pm 16,56$ & $2092,25 \pm 60,48^{*}$ & $700 \pm 17,66^{\#}$ & $1100 \pm 61,56^{\star *}$ \\
\hline Глюкоза, ммоль/л & $4,6 \pm 0,1$ & $11,2 \pm 0,2^{*}$ & $7,3 \pm 0,2^{\star \#}$ & $8,2 \pm 0,1^{\star *}$ \\
\hline IPI, пмоль/л & $221,74 \pm 20,79$ & $317,97 \pm 39,72^{*}$ & $280 \pm 21,81$ & $302 \pm 36,70^{*}$ \\
\hline
\end{tabular}

Примітки. Тут і в таблиці 2:

1. * - різниця достовірна відносно інтактної групи тварин $(p \leq 0,05)$.

2. * різниця достовірна відносно дексаметазону $(p \leq 0,05)$.

3. Декс - дексаметазон.

ванню у плазмі крові підлягає також альбумін, внаслідок чого утворюється фрруктозамін.

Підвищення концентрації фрруктозаміну та рівня базальної глікемії (табл. 1) в сироватці крові піддослідних тварин може свідчити про порушення регуляції глікемії інсуліном [16].

При введенні сухих екстрактів з листя стевії та чорниці на фроні їх сумісного введення з дексаметазоном спостерігали нормалізуючий вплив цих речовин на показники, які досліджували (табл. 1, 2). Так, за вказаних умов значно зменшувалися концентрація глікозильованого гемоглобіну, фрруктозаміну, рівень глюкози, площа під глікемічними кривими, а також рівень імунореактивного інсуліну. Останнє може бути пов'язане з високим вмістом у листі чорниці ряду фенольних сполук, для яких характерна гіпоглікеміча та антиоксидантна дія. Механізм гіпоглікемічної дії поліфенолів пов'язаний з їх впливом на процес транспорту глюкози у клітину. Головна роль у гіпоглікемічній дії екстракту з листя чорниці належить міртиліну, що являє собою суміш ефрірів дельвінідину і мальвінідину, які підвищують чутливість клітин до інсуліну [17], а екстракту 3 листя стевії - стевіозиду (компоненту листя стевії), введення якого знижує рівень глюкози, глікозильованого гемоглобіну в крові пацієнтів із цукровим діабетом $[1,3,4]$.

Отже, встановлені ефекти досліджених екстрактів можна пояснити високим вмістом глікозидів екстракту 3 листя стевії та поліфенолів екстракту з листя чорниці, а також їх сумісною дією.

Доведено, що гіперглікемія супроводжується активацією вільнорадикальних процесів, що обтяжує пошкодження органів і тканин. У таблиці 2 показано, що при введенні щурам низьких доз дексаметазону в їх печінці спостерігали зростання вмісту ТБК-РАП та ДК (первинних продуктів ліпопероксидації), яке корелювало зі зменшенням вмісту GSH і ГР, що вказувало на збільшення вмісту показників ліпопероксидації та зменшення вмісту показників антиоксидантного статусу. Введення сухих екстрактів 3 листя стевії та чорниці на фроні їх сумісного введення 3 дексаметазоном нормалізувало показники ліпопероксидації та антиоксидантного статусу організму піддослідних лабораторних тварин, що, ймовірно, зумовлено антиоксидантними властивостями екстрактів з листя чорниці та стевії, причому дані ефректи більш виразно проявляються при введенні екстрактів з листя чорниці.

Таблиця 2 - Вміст ТБК-реактивних продуктів, дієнових кон'югатів,

відновленого глутатіону і глутатіонредуктази в печінці щурів при введенні дексаметазону та екстрактів 3 листя стевії або чорниці ( $\mathrm{M} \pm \mathrm{m}, \mathrm{n}=6)$

\begin{tabular}{|l|c|c|c|c|}
\hline \hline \multicolumn{1}{|c|}{ Показник } & Інтакт & Дексаметазон & Декс+стевія & Декс+чорниця \\
\hline ТБК-РАП, нмоль/г & $0,96 \pm 0,27$ & $3,56 \pm 0,41^{*}$ & $2,74 \pm 0,32$ & $0,98 \pm 0,39^{*}$ \\
\hline ДК, нмоль/л & $22,30 \pm 1,42$ & $28,5 \pm 0,94^{*}$ & $27,1 \pm 0,98$ & $26,9 \pm 0,96$ \\
\hline GSH, ммоль/г & $0,25 \pm 0,01$ & $0,12 \pm 0,02^{*}$ & $0,21 \pm 0,02$ & $0,19 \pm 0,03$ \\
\hline ГР, нмоль/хв·мг білка & $18,56 \pm 0,64$ & $14,20 \pm 1,06^{*}$ & $15,2 \pm 0,73^{*}$ & $17,9 \pm 0,98$ \\
\hline
\end{tabular}

ВИСНОВКИ. Використання сухих екстрактів з листя стевії та чорниці проявляє нормалізуючу дію на показники глікозилювання, рівень глюкози, показники ліпідного обміну в сироватці крові щурів при цукровому діабеті 2 типу. Показано більш виражену антиоксидантну дію екстракту з листя чорниці та гіпоглікемічну дію екстракту з листя стевії. Це свідчить про доцільність сумісного застосування екстрактів 3 листя стевії та чорниці з метою створення на їх основі лікарських засобів для корекції метаболічних порушень. 


\section{СПИСОК ЛІТЕРАТУРИ}

1. Gregersens S. Antihyperglycemic effects of stevioside in type 2 diabetic subjects / S. Gregersens, P. B. Jeppesen, J. J. Holst // Metabolism. - 2004. - 53, № 1. - P. 73-76.

2. Baby Joseph. In sight the hypoglycaemic effect of traditional Indian herbs used the teratment of diabetes / Joseph Baby, D. Jini Rjmp // IJPT. - 2011. - 4. - P. 352375.

3. Buren J. Dexamethasone decreases GLUT 1 and GLUT4 content in primary cultured rat adipocytes / J. Buren, J. Ereksson // Diabetol. - 1999. - 42, № 1. - P. 170.

4. European convention for the protection of vertebrate animals used for experimental and other scientific purposes Strasbourg: Council of Europe, 1986. - 53 p.

5. Effects of stevia, aspartate, and sucrose on food intake, satiety, and postprandial glucose and insulin levels / S. D. Artoni, C. K. Martin, H. Han [et al.] // Appetite. - 2010. - 55, № 1. - P. 37-43.

6. Барчук О. 3. Визначення вмісту БАР в екстрактах 3 листя чорниці звичайної / О. 3. Барчук, Л. В. Вронська // Фармак. часоп. - 2012. - № 1. С. $60-63$.

7. Зворська О. Чорниця звичайна (Vaccinium myrtillus L.) - перспективна речовина для одержання лікарських засобів / О. Зворська, Т. Грошовий // Фармак. часоп. - 2009. - № 3. - С. 29-33.

8. Рязанова Т. К. Фармакологическое исследование плодов и побегов черники обыкновенной / Т. К. Рязанова // Фундаментал. исследования. - 2013. - № 8 , ч. 5. - С. $1136-1140$.

9. Reddy K. J. The role of the insulin resistance in the pathogenesis of atherosclerotic cardiovascular di-

\section{REFERENCES}

1. Gregersens S., Jeppesen, P.B., \& Holst, J.J. (2004). Antihyperglycemic effects of stevioside in type 2 diabetic subjects. Metabolism, 53.

2. Baby Joseph, \& D. Jini Rjmp (2011). In sight the hypoglycaemic effect of traditional indian herbs used the teratment of diabetes. IJPT, 42 (1), 170.

3. Buren, J. (1999). Dexamethasone decreases GLUT 1 and GLUT4 content in primary cultured rat adipocytes. Diabetol., 71 (2), 108-113.

4. European convention for the protection of vertebrate animals used for experimental and other scientific purposes. Strasbourg: Council of Europe, 8 (2) 109-116.

5. Artoni, S. Martin, C.K. \& Han, H. (2010). Effects of stevia, aspartate, and sucrose on food intake, satiety, and postprandial glucose and insulin levels. Appetite, 55 (1), 37-43.

6. Barchuk, O.Z., \& Vronska, L.V. (2012). Vyznachennia vmistu BAR $v$ ekstraktakh z lystia chornytsi zvychainoi [Determination of BAS content in extracts from blueberry leaves ordinary]. Pharmakolohichnyi chasopys - Pharmacological Journal, 1, 60-63 [in Ukrainian].

7. Zvorska, O., \& Hroshovyi, T. (2009). Chornytsia zvychaina (Vaccinium myrtillus L.) - perspektyvna seases: an uptated review/K. J. Reddy // J. of Carviovasc. Med. - 2010. - 11, № 9. - P. 633-647.

10. Salamar M. R. Relationships among insulin resistance, obesity, diagnosis of the metabolic syndrome and cardio-metabolic risk / M. R. Salamar // Diabetes and Cardiovasc. Dis. Res. - 2014. - 8, № 2. - P. 109-116.

11. Строев Е. А. Практикум по биологической химии / Е. А. Строев, В. Г. Макарова. - М. : Высш. шк., 1986. $-231 \mathrm{C}$

12. Энциклопедия народной медицины / уклад. i відп. ред. О. Михайлевський. - Львів : Сполом, 2005. Т. 1. $-1284 \mathrm{c}$.

13. Mechanism of the hypoglycemic effects of stevioside, a glycoside of stevia rebaudiana / T. H. Chen, S. C. Chen, P. Chan [et al.] // Planta Med. - 2005. - 71, № 2. - P. 108-113.

14. Ильин А. В. Гликозилированный гемоглобин как ключевой параметр при мониторинге больных сахарным диабетом / А. В. Ильин, М. И. Арбузова, А. П. Князева // Сахарный диабет. - 2008. - № 2. C. $60-64$.

15. Low-dose dexamethosone in the rat: a model to study insulin resistance / C. Severino, P. Brizzi, A. Solinas [et al.] // Amer. J. of Physiol. - 2012. - 283, № 2. P. 367-373.

16. Ивашкин В. Т. Липотоксичность и метаболические нарушения при ожирении / В. Т. Ивашкин // Гастроэнтерология, гепатология, колопроктология. 2010. - 2, № 1. - C. 4-13.

17. Макарова М. Н. Антирадикальная активность фрлавоноидов и их комбинаций с антиоксидантами / М. Н. Макарова, В. Г. Макаров // Фармація. - 2004. № 2. - C. 30-32.

rechovyna dlia oderzhannia likarskykh zasobiv [Blueberries usual (Vaccinium myrtillus L.) - a promising substance for the obtaining of medicinal drugs]. Pharmakolohichnyi chasopys - Pharmacological Journal, 3, 29-33 [in Ukrainian].

8. Ryazanova, T.K. (2013). Farmakologicheskoe issledovanie plodov i pobegov cherniki obyknovennoy [Pharmacological study of fruits and shoots of blueberry]. Fundamentalnye issledovaniya - Fundamental Research, 8 (5), 1136-1140 [in Russian].

9. Reddy, K.J. (2010). The role of the insulin resistance in the pathogenesis of atherosclerotic cardiovascular diseases: an uptated review. J. of Carviovasc. Med., 9, 633-647.

10. Salamar, M.R (2014). Relationships among insulin resistance, obesity, diagnosis of the metabolic syndrome and cardio-metabolic risk. Diabetes and Cardiovasc. Dis. Res., 2 (283), 367-373.

11. Stroev, E.A. \& Makarova, V.G. (1986). Praktikum po biologicheskoy khimii [Workshop on Biological Chemistry]. Moscow: Vyssh. shk. [in Russian].

12. Mikhalevskiy, O. (Ed.). (2005). Entsyklopedia narodnoy meditsiny [Encyclopedia of traditional medicine]. Lviv: Spolom [in Russian]. 
13. Chen, T.H., Chen, S.C., \& Chan, P. (2005). Mechanism of the hypoglycemic effects of stevioside, a glycoside of stevia rebaudiana. Planta Med., 53 (1), 73-76.

14. Ilyin A.V., Arbuzova, M.I. \& Knyazeva, A.P. (2008). Glikozilirovannyy gemoglobin kak klyuchevoy parametr pri minitoringe bolnykh sakharnym diabetom [Glycosylated hemoglobin as a key parameter in the monitoring of patients with diabetus mellitus]. Sakharnyy diabet Diabetes Mellitus, 2, 60-64 [in Russian].

15. Severino, C., \& Solinas, A. (2012). Low-dose dexamethosone in the rat: a model to study insulin resistance. Amer. J. of Physiol., 11 (9), 633-647.
16. Ivashkin, V.T. (2010). Lipotkichnost i metabolichiskie narusheniya pri ozhyrenii [Lipotoxicity and metabolic disorders in obesity]. Gastroenterologiya, gepatologiya, koloprologiya - Gastroenterology, Hepatology, Coloprology, 2 (1), 4-13 [in Russian].

17. Makarova M.N., \& Makarov, V.G. (2004). Antiradikalnaya aktivnost flavonoidov I ikh kombinatsiy s antioksidantami [Antiradical activity of flavonoids and their combinations with antioxidants]. Farmatsiia - Pharmacy, 2, 30-32 [in Ukrainian].

\section{ИССЛЕДОВАНИЕ ВЛИЯНИЯ ЭКСТРАКТОВ ИЗ ЛИСТЬЕВ СТЕВИИ И ЧЕРНИКИ НА ПОКАЗАТЕЛИ РАЗВИТИЯ ЭКСПЕРИМЕНТАЛЬНОГО САХАРНОГО ДИАБЕТА, ИНДУЦИРОВАННОГО ВИСОКОФРУКТОЗНОЙ ДИЕТОЙ С ДОБАВЛЕНИЕМ ИНЪЕКЦИЙ ДЕКСАМЕТАЗОНА}

\section{Резюме}

Вступление. Сахарный диабет 2 типа - метаболическое заболевание, характеризующееся хронической гипергликемией, которая развивается в результате нарушения секреции инсулина или механизмов его взаимодействия с клетками тканей. Известно, что главной причиной развития сердечно-сосудистых осложнений является гипергликемия.

Цель исследования - изучить влияние сухих экстрактов из листьев стевии и черники на развитие метаболических нарушений у крыс при экспериментальном сахарном диабете, вызванном дексаметазоном на фроне высокофруктозной диеты.

Методы исследования. В сыворотке крови определяли концентрацию гликозилированного гемоглобина, уровень фрруктозамина, площадь под гликемическими кривыми, уровень иммунореактивного инсулина. Показатели липопероксидации определяли по содержанию диеновых конъюгатов и ТБК-реактивных продуктов, состояние антиоксидантной системы оценивали путем определения концентрации восстановленного глутатиона. Значимость межгрупповых различий оценивали по t-критерию Стьюдента.

Результаты и обсуждение. Введение лабораторным животным низких доз дексаметазона вызвало комплекс нарушений, характерных для метаболического синдрома и диабета 2 типа. Так, в указанных условиях в сыворотке крови крыс наблюдали повышение уровня гликозилированного гемоглобина, концентрации фрруктозамина, содержания глюкозы, уровня базальной гликемии, увеличение площади под гликемическими кривыми. При введении сухих экстрактов из листьев стевии и черники на фроне их совместного введения с дексаметазоном отмечали нормализующее влияние этих веществ на исследуемые показатели.

Выводы. Использование сухих экстрактов из листьев стевии и черники оказывает нормализующее действие на показатели гликозилирования, уровень глюкозы, показатели липидного обмена в сыворотке крови крыс при сахарном диабете 2 типа. Показаны более выраженное антиоксидантное действие экстракта из листьев черники и гипогликемическое действие экстракта из листьев стевии. Это свидетельствует о целесообразности совместного применения экстактов из листьев стевии и черники с целью создания на их основе лекарственных средств для коррекции метаболических нарушений.

КЛЮЧЕВЫЕ СЛОВА: экстракт из листьев стевии (Stevia rebaudiana Bertoni); экстракт из листьев черники (Vaccinum myrtillus); сахарный диабет 2 типа; инсулинорезистентность; дексаметазон. 


\section{INVESTIGATION OF THE EFFECTS OF STEVIA AND BILBERRY LEAVES EXTRACT ON NHE PERFORMANCE OF DIABETES MELLITUS}

\section{Summary}

Introduction. Diabetes mellitus type 2 (DM 2) is a metabolic disease, which is characterized by chronic hyperglycemia. It develops as a result of insulin secretion disorder or mechanisms of its interaction with tissue cells. It is known that hyperglycemia is the main cause of cardiovascular complications development.

The aim of the study - to learn the effect of dry extracts from stevia and bilberry leaves on the metabolic disorders development in rats with experimental diabetes mellitus, caused by dexamethozone on a high-fructose diet ground.

Research methods. The concentration of glycosylated hemoglobin, the level of fructosamine, the area under the glycemic curves, the level of immunoreactive insulin have been determined in the serum. Lipoperoxidation indicators have been determined according to diene conjugates (DC) and TBA-reactive products (TBA-RAP) content, the state of the antioxidant system has been assessed by reduced glutathione concentration determining (GSH). The significance of intergroup differences have been assessed due to Student's t-criterion.

Results and Discussion. The introduction of low-dose dexamethasone in laboratory animals causes a complex of disorders, which are specific for metabolic syndrome and type 2 diabetes. Thus, a rise in the level of glycosylated hemoglobin, a concentration of fructosamine, a glucose level, a basal glycemia level, an increase in the area under the glycemic curves are observed in the serum of rats under the indicated conditions. With the introduction of dry extracts of stevia and bilberry leaves together with dexamethasone, the normalizing influence of these substances on the investigated indicators is observed.

Conclusions. The use of dry extracts from stevia and bilberry leaves has a normalizing effect on glycosylation indicators, glucose level and lipid metabolism in the rats' serum in type 2 diabetes mellitus. The more pronounced antioxidant effect of the extract from bilberry leaves and the hypoglycemic action of the extract from stevia leaves have been shown. This proves the advisability of the extracts from stevia and bilberry leaves joint application with the aim of drugs creation on their basis for metabolic disorders correction.

KEY WORDS: stevia leaf extract (Stevia rebaudiana Bertoni); bilberry leaf extract (Vaccinum myrtillus); type 2 diabetes; insulin resistance; dexamethasone.

Адреса для листування: О. І. Чумак, Національний фармацевтичний університет, вул. Пушкінська, 53, Харків, 61002, Україна, e-mail: 1108chumak@gmail.com. 